\title{
Evaluation of single-cross and trilineal hybrids with sul gene from mexican landraces
}

\begin{abstract}
Sweet corn is a vegetable eaten fresh. This research evaluates hybrid sweet maize carrying $s u 1$ gene. In the first stage 30 single-cross and 47 trilinear hybrids were evaluated in separate experiments using Alpha Lattice design. Results showed competence data on 11 hybrids, outstanding in yield and degrees Brix. Those were evaluated in a second stage in three separate experiments, using two environments with a randomized blocks design and eight repetitions. Significant differences were found $(\mathrm{P} \leq 0.01)$ between experiments, repetitions and treatments with higher yield and degrees Brix over reference items. By crossing native sweet maize with elite lines of non-sweet maize sweet hybrids with same sweetness and significant improvement of plant and corn quality for Mexican landraces were obtained.
\end{abstract}

Keywords: Maíz dulce, Dulcillo del Noroeste, sweet mexican hybrids, genetic improvement, gene $s u 1$
Volume 4 Issue 6 - 2020

\author{
José Alberto Sánchez-Nuño,' Lino De la \\ Cruz-Larios, 'Abraham Guerrero-Corona, ${ }^{2}$ \\ Moisés Martín Morales-Rivera,' Eduardo \\ Rodríguez-Guzmán,' Fernando Santacruz- \\ Ruvalcaba' \\ 'Universidad de Guadalajara, Centro Universitario de Ciencias \\ Biológicas y Agropecuarias (CUCBA), México \\ ${ }^{2}$ Instituto Tecnológico José Mario Molina Pasquel y Henríquez, \\ Unidad Académica Cocula, Mexico
}

\author{
Correspondence: Dr. Lino De la Cruz Larios, Universidad \\ de Guadalajara, Centro Universitario de Ciencias Biológicas y \\ Agropecuarias (CUCBA). Camino Ramón Padilla Sánchez 2100, \\ Nextipac, 44600 Zapopan, Jalisco, México, Tel 3313274355, \\ Email linocucba@hotmail.com
}

Received: October 23, 2020 | Published: December 0I, 2020

\section{Introduction}

Landraces Maíz Dulcillo del Noroeste and Maíz Dulce are considered special due to their antioxidants, vitamins, proteins, minerals, and sugar contents. "A total of 18 amino acids, crucial for human nutrition have been identified in the corn cob of sweet maize, including serine, glutamine, alanine, proline, and aspartic and glutamic acids", ${ }^{1}$ and "mineral components including potassium, calcium, sodium, magnesium, phosphorus, iodine and iron". ${ }^{2}$ Sweet corn also has a long tradition and multifunctionality in nutrition and customs; the great majority of it is marketed through improvised sites in highways, farmers markets, food markets, direct delivery to wholesales sites, and in supermarkets. It is also used to extract high fructose syrups. Sweet corn cobs "are one of the main products obtained from maize and are used to make corn flakes", ${ }^{3}$ and for making candies. Due to the importance of sweet corn it is necessary to work with it in genetic improvement programs.

Sweet corn has in its genome recessive alleles $s u 1 s u 1$ provoked by a "spontaneous mutation in $s u 1$ gene (sugary 1 ) controlling sugar conversion into starch inside the endosperm of the maize grain". ${ }_{4}$ With and alteration of the nucleotide sequence in a "fixed position called $s u 1$, located in chromosome 4 Bin 4.05 ". "The historically most important sweet mutant $s u 1$ produces grains with high phytoglycogen content". ${ }^{6}$ This recessive gene causes polysaccharides soluble in water to raise increasing sweetness. Improved hybrid maize from genetically pure lines with allele $s u 1 s u 1$ present high soluble solids in general, such as phytoglycogen, increasing sugar levels and percentages of $\left({ }^{\circ} \mathrm{Bx}\right)$ degrees Brix, which is the indicator measure used in experimental tests to determine food sweetness in the food industry and to detect sweet grain genotypes for producing seeds and hybrids. A problem existing in Mexico regarding improved seeds and hybrids of sweet maize offer is that it is restricted to hybrids with very limited adaptation to seasonal rain and to certain areas of Mexico. Up to now private and public institutions in Mexico have no knowledge of sweet maize hybrid seeds adapted to seasonal rain which can function as forage. For this reason, it is important to generate quality hybrids of sweet maize which can adapt to temperate and semi-warm subhumid climates. The present research work has the aim to evaluate singlecross and trilinear hybrids with $s u 1$ gene having good agronomic characteristics to benefit consumer, such as yield, length, diameter, sweetness and quality of plant and corn.

\section{Materials and methods}

The germplasm used as donor progenitor was composed by accessions of landrace Maíz Dulce: Chihuahua (Chih-194 from Balleza and Chih-200 from Guachochi), Guanajuato (Gto-181 from Silao), Jalisco (Jal-300 from Mezquitic, M09476 and M09477 from Huejucar) and Michoacán (M06193 from Tarímbaro and M06173 from Huandacareo); of landrace Dulcillo del Noroeste: Nayarit (Nay47 from Tuxpan) and Sonora (Son-85 from Rosario), and of elite progenitors of no sweet maize of dented grain LUG282, LUG03, CML78 and CML311 used as recurrent progenitors, which are lines of improvement from (IMAREFI) Instituto de Manejo de Recursos Fitogenéticos at (CUCBA) Centro Universitario de CienciasBiológicas y Agropecuarias from Universidad de Guadalajara, and (CIMMYT) International Maize and Wheat Improvement Center.

Crossings of the recurrent progenitor (pure lines) with donor progenitor (sweet maize landraces) were carried out. $F_{1}$ was planted and at harvest, maize grains with sweet grain type characteristics were selected. These are grains with rough aspect in ear stage. They were planted and self-pollinated for several cycles until pure recombinant sweet lines were obtained which latter generated single-cross and trilinear hybrids.

Crossing evaluation was carried out in two locations in the state of Jalisco: CUCBA, Nextipac, municipality of Zapopan, Jalisco, with coordinates $20^{\circ} 44^{\prime} 42^{\prime \prime} \mathrm{N}$ and $103^{\circ} 30^{\prime} 54^{\prime \prime} \mathrm{W}$, altitude 1658 masl, annual average temperature $18^{\circ} \mathrm{C}$, annual precipitation of 850 $1000 \mathrm{~mm}$, and subhumid climate; and in El Salitre, municipality of 
San Martín Hidalgo, Jalisco, with coordinates: 20³0'33.9' N and $103^{\circ} 51^{\prime} 01.4^{\prime \prime} \mathrm{W}$, altitude 1260 masl and annual precipitation of 964 $\mathrm{mm}$. annual average temperature $20.9^{\circ} \mathrm{C}$ and semidry.

Field work was carried out in three stages; in stage one 47 crossings with four repetitions and a commercial reference, Golden Sweet were evaluated. In a second experiment 30 single-cross with two repetitions, and Golden Sweet, included as reference were evaluated. These experiments were planted in the summer cycle of 2015 in the experimental field at CUCBA. Evaluated variables were: (FF) days for female flowering, (FM)days for male flowering, (AMZ) ear height, (ALPL) plant height, (Peso25) and (Peso35) ear weight at 25 and 35 days after flowering and respectively, (DiaM) ear diameter, (LonM) ear length, $\left({ }^{\circ} \mathrm{Bx} 25\right)$ and $\left({ }^{\circ} \mathrm{B} \times 35\right)$ sugar content at 25 and 35 days after flowering respectively, (Hil) number of grain rows, and (Grxhil) number of grains per row. Experimental units were made in two furrows $4.00 \mathrm{~m}$ length separated by $0.75 \mathrm{~m}$ with 50 total plants. Samples consisted of ten corns for weight and three for sweetness $\left({ }^{\circ} \mathrm{Bx}\right)$, took randomly.

In the second stage parental seeds of the best recombinant lines were incremented to form trilinear hybrids, based on the results of the first stage. These seeds were planted in greenhouse conditions with drip irrigation systems in the winter 2015-2016. Parental increments and hybrid formations were done through manual pollination. In the third stage, during the spring-summer cycle 2016, the best 11(HT) trilinear hybrids were evaluated, as well as the best (HS) single-cross hybrids regarding best yield and corn sweetness from the first stage. Hybrid Golden Sweet and a native corn (Jayamitla) were used as references. They were evaluated in three independent experiments with different planting dates in two locations: El Salitre municipality of San Martin de Hidalgo, Jalisco, and in Nextipac, municipality of Zapopan, Jalisco. The evaluation was carried out with a complete block design and eight repetitions each. Experimental units were in four furrows $4.00 \mathrm{~m}$ length with. $75 \mathrm{~m}$ separation between furrows, with 50 total plants. Measured variables were the same as those in stage one, $\left({ }^{\circ} \mathrm{B} \times 25 \mathrm{r} 30\right.$ and $\left.{ }^{\circ} \mathrm{B} \times 35 \mathrm{r} 30\right)$ plus sweetness at 25 and 35 days after flowering and refrigerated for 30 days. Sugar percentages were measured with a digital refractometer Atago PAL-1. Table 1 shows genealogy of the 11 hybrids which participated in the third stage evaluations.

Table I Hybrids genealogy. Evaluation in 2016 T

\begin{tabular}{ll}
\hline Treatments & Trilinear crosses \\
\hline Trilinear crosses8 & Csdulce-x(LUG-03XNAYA-47_Plant I2)F2-2-I-I-M-I \\
Trilinear crosses I0 & Csdulce-x(LUG-03XGTO-I8I_Plant I4)F2-4-2-3-M-I \\
Trilinear crosses I2 & Csdulce-x(LUG-03XJAL-300_Plant9)F2-2-3-I-I-M \\
Trilinear crosses I6 & Csdulce-x(LUG-03XNAYA-47_Plant I2)F2-2-I-I-M-2 \\
Trilinear crosses I8 & Csdulce-x(LUG-03XNAYA-47_Plant I2)F2-4-4-4-I-M \\
Trilinear crosses20 & Csdulce-x(LUG-03XM-06I93_Plant I 2)F2-3-I-I-I-I \\
Trilinear crosses2I & Csdulce-x(LUG-03XGTO-I8I_Plant I2)F2-2-I-3-M-I \\
Trilinear crosses29 & Csdulce-x(LUG-03XJAL-300_Plant8)F2-I-I-4-I-M \\
Trilinear crosses36 & Csdulce-x(LUG-03XNAYA-47_Plant I2)F2-4-4-5-I-M \\
Single crosses II & Single crosses \\
Single crosses I9 & [LUG-03XM-06I93_PI2)F2-I-2-I-I-M]xLMdulce \\
GS & CS_Dulcex(Commercial hyb x M06030-49-I-I) \\
Test & Golden sweet \\
\hline
\end{tabular}

Fertilizers were applied in the following way: $200 \mathrm{~kg} / \mathrm{ha}$, MAP (18-46-00) at planting, and two applications of urea $200 \mathrm{~kg} / \mathrm{ha}$ (46-00$00)$, the first one when plants had five true leaves and the second when plants were in flowering stage. Herbicides Convey (Topramezone 33, $6 \%$ ) and Atrazina with a dosage of $4 \mathrm{Lha}^{-}{ }^{-}$were applied, with manual sprayer and fan nozzle number 4 aiming to weeds. Foliar fertilizer Bayfolan ${ }^{\circledR}$ S 4 Lha- ${ }^{1}$, containing macronutrients and micronutrients was applied with backpack sprayer and directed cone nozzle pointing to corn plants; biological farming insecticide (Palgus Spinetoram: mixture of Spinosyn J and Spinosyn L) $3 \mathrm{Lha}^{-}{ }^{1}$ was also applied.

\section{Statistical analysis}

With the quantitative data obtained in field and laboratory an ANOVA and means comparison tests by treatment for each variable were carried out. Means were adjusted with a (GLM) generalized linear model adjusted by least squares (LSMEANS) with the program SAS $^{\circledR} 9.0$ and ANOVA with a combined model of the two evaluation stages simulating different environments.
The model for the experiments was alpha lattice:

Where: $Y_{\mathrm{ij} 1}=\mu+\tau_{\mathrm{i}}+\gamma_{\mathrm{j}}+\rho_{1}\left(\mathrm{j}_{\mathrm{j}}\right)+\varepsilon_{\mathrm{ij} 1}$

Yijl $=$ Value of each variable in each experimental unit

$\tau_{\mathrm{i}}=$ Effect of treatments

$\gamma_{\mathrm{j}}=$ Effect of repetitions

$\rho_{1}\left({ }_{j}\right)=$ Effect of incomplete blocks

$\varepsilon_{\mathrm{ijl}}=$ Random error

\section{Results and discussion}

Variance analysis (Table 2) for trilinear hybrids HT presented differences highly significant $(\mathrm{P} \leq 0.01)$ among treatments for all variables, except for $\left({ }^{\circ} \mathrm{Bx} 25\right)$. Nevertheless, there were important numerical differences in means comparison and percentages obtained in laboratory tests for this variable. This can be attributed partly to the pure lines utilized as base; the genotypes presented the same 
sweet $s u 1$ gene but from a different geographic origin. There was also an intrinsic genetic variability among genotypes behaving with a sweetness increment from 25 to 35 days after flowering, in accordance with Xu et al. ${ }^{7}$ In the variance analysis for single-cross HSs there were significant differences $(\mathrm{P} \leq 0.05)$ in treatments for the great majority of variables indicating variability in the evaluated genotypes, as can be seen in Table 3. Characters in quality of corn from sweet maize are complex as they depend on quantitative characters and the sugar content depends on recessive genes; nevertheless, Luch singer and Camilo $^{8}$ point out that taking as reference a commercial item, sugar contents for the evaluated hybrids would be considered of good quality. The effect on significance $(\mathrm{P} \leq 0.01)$ was represented in four variables taken into account in the experiment which indicates that at least one block was different from the rest. This is attributed to the effects of environmental genotypes evaluated in the random incomplete blocks which caused differences in weights and degrees of sweetness on corn per experimental unit. HTs showed significant differences in quality, compared to reference item. These results are in accordance with similar studies made by Michaels and Andrew. ${ }^{9}$ In our work, germplasm lines of Nay-47 (Dulcillo delNoroeste) stands out as can be seen in Table 5 .

Table 2 ANOVA: Sweet trilinear hybrids CUCBA 2015

\begin{tabular}{lllllll}
\hline Variable & CME & CMR & CMB & CMT & CV & Mean \\
\hline Peso25 & 42963 & 53265.6 & $106256^{* *}$ & $116185.4^{* *}$ & 10.4 & $1985.2 \mathrm{~kg}$ \\
Peso35 & 47430.1 & 56406.6 & $139757.4^{* *}$ & $108216.9 * *$ & 10.5 & $2068.6 \mathrm{~kg}$ \\
${ }^{\circ} \mathrm{B} \times 25$ & 18.9172 & 34.2641 & 13.24 & 21.8598 & 19.49 & $22.32{ }^{\circ} \mathrm{Bx}$ \\
${ }^{\circ} \mathrm{B} \times 35$ & 23.0757 & 3.3417 & 19.3472 & $80.2798^{* *}$ & 20.21 & $23.77^{\circ} \mathrm{Bx}$ \\
LonM & 1.4177 & 0.3165 & 1.9002 & $6.6599^{* *}$ & 6.68 & $17.82 \mathrm{~cm}$ \\
DiaM & 0.027 & 0.0523 & $0.0659^{* *}$ & $0.1353^{* *}$ & 3.43 & $4.79 \mathrm{~cm}$ \\
Hil & 0.755 & 0.2266 & 0.5013 & $6.8279 * *$ & 6.02 & 14.44 rows \\
Grxhil & 7.2302 & 4.9222 & 7.5096 & $28.8331^{* *}$ & 7.7 & 34.94 grains \\
Ff & 2.4692 & 0.4417 & 3.7008 & $26.7829 * *$ & 2.37 & 66.31 days \\
Fm & 2.8154 & 0.2063 & 4.3762 & $26.3303^{* *}$ & 2.55 & 65.89 days \\
Alpl & 0.0173 & 0.0364 & $0.1193^{* *}$ & $0.1114^{* *}$ & 6.37 & $2.06 \mathrm{~m}$ \\
Amz & 0.0191 & $0.0739 *$ & $0.0373^{*}$ & $0.0877^{* *}$ & 12.87 & $1.07 \mathrm{~m}$ \\
GL & 105 & 3 & 12 & 39 & & \\
\hline
\end{tabular}

†ANOVA CME, CMR, CMB, CMT, mean squared error, repetitions, blocks in repetitions, and treatments respectively; GL, degrees of freedom; CV, coefficient of variation; Mean, general mean of the experiment; $\mathrm{Fm}$, days for male flowering; $\mathrm{Ff}$, days for female flowering; $\mathrm{B} \times 25$ and $\mathrm{B} \times 35$, quantity of sugar in degrees Brix at 25 and 35 days after flowering, respectively; peso 25 and Peso35, weight in $\mathrm{kg}$ of ten fresh ears of corn at 25 and 35 days after flowering, respectively; LonM and $\mathrm{DiaM}$, ear of corn length and diameter in cm, respectively; Hil, number of grain rows, Grxhil, number of grains by row; Alpl, plant height in m; Amz, ear of corn height in $\mathrm{m}$, Controls $=*=\mathrm{P} \leq 0.05, * *=\mathrm{P} \leq 0.01$

Table 3 ANOVA: Sweet single and trilinear hybrid CUCBA 2015T

\begin{tabular}{lllllll}
\hline Variable & CME & CMR & CMB & CMT & CV & Mean \\
\hline Peso25 & 38686.45 & $168363.38^{*}$ & 49160.1 & 60534.55 & 10.58 & $1858.86 \mathrm{~kg}$ \\
Peso35 & 37011.86 & 110081.67 & 27175.42 & $75585.64^{*}$ & 10.06 & $1912.72 \mathrm{~kg}$ \\
${ }^{\circ} \mathrm{B} \times 25$ & 7.9891 & 32.4625 & 8.7571 & $16.1096^{*}$ & 13.03 & $21.699^{\circ} \mathrm{bx}$ \\
${ }^{\circ} \mathrm{B} \times 35$ & 12.6378 & 16.4327 & 24.091 & $29.917^{*}$ & 15.71 & $22.62^{\circ} \mathrm{bx}$ \\
LonM & 1.7197 & 1.1252 & 2.342 & $3.696^{*}$ & 7.55 & $17.36 \mathrm{~cm}$ \\
DiaM & 0.0232 & 0.0634 & 0.0122 & $0.0624^{*}$ & 3.22 & $4.73 \mathrm{~cm}$ \\
Hil & 0.6607 & 0.15 & 0.3574 & $1.4598^{*}$ & 5.84 & 13.93 rows \\
Grxhil & 4.1655 & 8.563 & 8.2625 & $18.0586^{* *}$ & 5.91 & 34.54 grains \\
Ff & 1.9268 & 4.2667 & 3.4125 & $6.6549^{*}$ & 2.04 & 68.20 days \\
Fm & 2.4351 & 1.0667 & 4.1667 & 4.8322 & 2.31 & 67.50 days \\
Alpl & 0.0752 & 0.0175 & 0.0464 & $0.1653^{*}$ & 13.08 & $2.10 \mathrm{~m}$ \\
Amz & 0.024 & 0.0001 & 0.0227 & $0.0646^{*}$ & 14.85 & $1.04 \mathrm{~m}$ \\
GL & 19 & 1 & 10 & 29 & & \\
\hline
\end{tabular}

† ANOVACME, CMR, CMB, CMT, mean squared error, repetitions, blocks in repetitions, and treatments respectively; GL, degrees of freedom; CV, coefficient of variation; Mean, general mean of the experiment; $\mathrm{Fm}$, Days for male flowering; Ff, days for female flowering; Bx 25 and Bx35, quantity of sugar in degrees Brix at 25 and 35 days after flowering, respectively; Peso25 and Peso35, weight in $\mathrm{kg}$ of ten fresh ears of corn at 25 and 35 days after flowering, respectively; LonM and DiaM, ear of corn length and diameter in cm, respectively; Hil, number of grain rows, Grxhil, number of grains by row; Alpl, Plant height in m;Amz, Ear of corn height in $\mathrm{m}$, Controls $=*=\mathrm{P} \leq 0.05, * *=\mathrm{P} \leq 0.01$ 
Values for total solid soluble contents quality $32.2{ }^{\circ} \mathrm{Bx}$ were obtained, other works as the one from Coutiño et al. ${ }^{10}$ presented sugar contents of $13.8^{\circ} \mathrm{Bx}$. It was observed that maize genotypes with $s u 1$ gene maintain high sugar concentrations and can have an advantage in yield, crop and commercialization, according to works carried out by Michaels and Andrew, ${ }^{9}$ Marshall et al, ${ }^{11}$ \& Tracy et al. ${ }^{12}$ regarding quality associated with sugar concentrations and shelf life.

In means comparative tests, considering weight for 10 corns higher than $2.300 \mathrm{~kg}$, the significant treatments were 8,16 and 36 , and for diameter, treatments 10 and 21. It is important to point out that genealogies of these treatments were lines with germplasm LUG03 per accessions of landraces Dulcillo del Noroeste from Nayarit and Maíz Dulce from Guanajuato. These treatments, with good quantitative characteristics besides having values of $23^{\circ} \mathrm{Bx}$ are good options regarding corn quality.

Table 4 shows combined variance analysis. For this analysis, all variables were significant and/or highly significant, that is, there was interaction with the environment so individual analyses were taken for each variable and locality. On the other hand, there was no significant interaction in the combined analysis for variables $\left({ }^{\circ} \mathrm{B} \times 25 \mathrm{r} 30\right)$ and $\left({ }^{\circ} \mathrm{B} \times 35 \mathrm{r} 30\right)$. In this evaluations sugar was increasing in the grains as the days after flowering passed by, but all hybrids lowered their sugar concentration after being refrigerated which was observed in the corns harvested at 35 days after flowering (Table 5). Sucrose synthesis affects sugar concentrations in tissues due to changes in assimilate distribution as grains mature. ${ }^{?}$

Table 4 ANOVA: Combined analysis of II simple and Trilinear hybrids 2016 T

\begin{tabular}{llllllll}
\hline Variable & CME & CMExp & CMR & CMT & CMI & CV & Mean \\
\hline Peso25 & 0.0899 & $27.2546 * *$ & 0.0883 & $0.3641^{* *}$ & $0.1833^{*}$ & 18.9 & $1.59 \mathrm{~kg}$ \\
Peso35 & 0.0768 & $31.0785^{* *}$ & 0.0786 & $0.4655^{* *}$ & $0.2724^{* *}$ & 18.71 & $1.48 \mathrm{~kg}$ \\
${ }^{\circ} \mathrm{B} \times 25$ & 12.3942 & $458.9086^{* *}$ & 14.7428 & $88.1489^{* *}$ & $19.5045^{*}$ & 18.48 & $19.06^{\circ} \mathrm{Bx}$ \\
${ }^{\circ} \mathrm{B} \times 25 \mathrm{r} 30$ & 35.3044 & 784.0064 & $36.356 \mathrm{I}$ & $109.2034^{*}$ & 38.7985 & 32.54 & $18.26^{\circ} \mathrm{Bx}$ \\
${ }^{\circ} \mathrm{B} \times 35$ & 11.0406 & $42.7767^{*}$ & 14.9586 & $219.6678^{* *}$ & $33.9827^{* *}$ & 13.96 & $23.80^{\circ} \mathrm{Bx}$ \\
${ }^{\circ} \mathrm{B} \times 35 \mathrm{r} 30$ & 24.9862 & 16.5506 & 10.6511 & $130.2333^{* *}$ & 39.5412 & 28.11 & $17.79{ }^{\circ} \mathrm{Bx}$ \\
LonM & 5.1037 & $238.7827^{* *}$ & 2.5036 & $21.0563^{* *}$ & $11.7458^{*}$ & 14.03 & $16.10 \mathrm{~cm}$ \\
DiaM & 0.1177 & $18.2622^{* *}$ & 0.1401 & $0.4873^{* *}$ & $0.2547^{*}$ & 8.19 & $4.19 \mathrm{~cm}$ \\
Hil & 1.1182 & $27.5927^{* *}$ & 1.0015 & $11.0532^{* *}$ & $2.5949 *$ & 7.09 & 14.91 rows \\
Grxhil & 29.4268 & $1853.69 * *$ & 23.495 & $129.7332^{* *}$ & $63.6234^{*}$ & 16.45 & 32.97 grains \\
GL & 257 & 3 & 24 & 11 & 32 & &
\end{tabular}

† ANOVACME, CMExp, CMR, CMT, CMI, mean squared error, experiments, repetitions, treatments, and experiments per treatment, respectively; GL, degrees of freedom; CV, coefficient of variation; Media, general mean of the experiment; Bx25, Bx35, quantity of sugar in degrees Brix at 25 and 35 days after flowering, respectively; $\mathrm{B} \times 25 \mathrm{r} 30$ and $\mathrm{B} \times 35 \mathrm{r} 30$, Quantity of sugar in degrees Brix at 25 and 35 days after flowering and refrigerated for 30 days after harvesting, respectively; Peso25 and Peso35, weight in kg of ten fresh ears of corn at 25 and 35 days after flowering respectively; LonM and DiaM, ear of corn length and diameter in $\mathrm{cm}$, respectively; Hil, number of grain rows, Grxhil, number of grains per row; Controls $=*=\mathrm{P} \leq 0.05$, $* *=\mathrm{P} \leq 0.0 \mathrm{I}$

Table 5 Adjusted means of II hybrids in three individual experiments $2016 \mathrm{~T}$

\begin{tabular}{|c|c|c|c|c|c|c|c|c|c|}
\hline \multirow[t]{2}{*}{ Trat } & Cucba I & Cucba 2 & Salitre & Cucba I & Cucba 2 & Salitre & Cucba I & Cucba2 & Salitre \\
\hline & \multicolumn{3}{|c|}{$\mathrm{Kg} \mathrm{IO}$ ears at 25 daf } & \multicolumn{3}{|c|}{${ }^{\circ} \mathrm{Bx}$ at 25 daf } & \multicolumn{3}{|c|}{${ }^{\circ} \mathrm{Bx}$ at 35 daf } \\
\hline HT8 & 1.98 & $1.7^{* *}$ & 0.82 & $17.9 * *$ & $19.6 * *$ & 19.5 & $24.3^{* *}$ & $28.5^{* *}$ & 24.3 \\
\hline HTIO & 2.13 & $1.67 * *$ & 0.7 & 16.5 & 15.6 & 18.8 & $20.4 * *$ & $23.9 * *$ & $22.9 * *$ \\
\hline hsII & 1.91 & 1.73 & 1.09 & $18.5^{* *}$ & 18 & 19 & $22.5^{* *}$ & $23.4^{* *}$ & 24.3 \\
\hline HTI2 & 2.03 & $1.67 *$ & 1.03 & $18 * *$ & $18.4^{*}$ & 20.8 & 22.4 & $25.3^{* *}$ & $25.6 * *$ \\
\hline HTI6 & 2.08 & $1.53 * *$ & 0.87 & $17.7^{* *}$ & $20.7^{* *}$ & 20.8 & $23.8^{* *}$ & $26.2^{* *}$ & $25.6 * *$ \\
\hline HTI8 & 1.91 & $1.68 * *$ & 1.09 & 16.2 & $22 * *$ & 19.8 & $25.6 * *$ & $25.7 * *$ & 24.2 \\
\hline hs 19 & 2.08 & $1.65^{*}$ & 0.42 & 16.2 & $18.9 *$ & 19.2 & 22 & $25.1^{* *}$ & $25.7 * *$ \\
\hline HT20 & 2.19 & 1.56 & 0.99 & $17.2^{*}$ & $20.3^{* *}$ & 20.8 & $23.3^{* *}$ & $24.1 * *$ & $22.5 * *$ \\
\hline HT2I & 2.28 & $1.9 * *$ & 0.73 & $17.4^{*}$ & $18.5^{*}$ & 19.2 & $25.5^{* *}$ & $26.9 * *$ & $22.3^{*}$ \\
\hline НT29 & 1.93 & 1.49 & 0.66 & $20.4^{* *}$ & 15.5 & $22.6 * *$ & $26.5^{* *}$ & $27.5^{* *}$ & $22.9 * *$ \\
\hline HT36 & 2.3 & $1.68 * *$ & 1.07 & $17.8^{* *}$ & $18.9 *$ & 18.6 & $25.4 * *$ & $26.5^{* *}$ & $22 *$ \\
\hline TEST & 2.06 & 1.18 & 0.88 & 11.8 & 12.5 & 16.9 & 14.1 & 8.7 & 17.1 \\
\hline
\end{tabular}

†Means of most representative variables:Trat, Treatments; HT,Trilinear hybrids; hs, Single hybrids; Test, Reference; daf, days after flowering; Controls, * $=$ P $\leq .05$; $* *=\mathrm{P} \leq 0.01$ 
Table 5 shows the adjusted means for hybrids evaluated in two environments but three different planting dates A remarkable superiority was observed in different variables associated with corn quality for hybrids compared to reference items used in different localities and which were not significant in any environment or any variable studied, compared with trilinear and single hybrids which were significant. For example, HTs were superior and more competitive than HSs in variables $\left({ }^{\circ} \mathrm{B} \times 25\right)$ and $\left({ }^{\circ} \mathrm{B} \times 35\right)$. The best results in sweetness expression were from trilinear hybrids and happened in the experiment done in the second planting date in CUCBA2, where significant treatments were 12, 20 and 21, coming from landrace Maíz Dulce, accessions from the states of Jalisco, Michoacán and Guanajuato, and for treatments 16 and 18 for landrace Dulcillo del Noroeste with hybrid accessions from Nayarit. Authors like Ramírez-Díaz et al. ${ }^{13}$ have considered that native corns presents lots of similarities to exotic germplasm coming from other regions of the world; both can be a source of useful allele but they can also

Table 6 (Continuation):Adjusted means of II hybrids in three individual experiments2016 T

\begin{tabular}{|c|c|c|c|c|c|c|c|c|c|}
\hline \multirow[t]{2}{*}{ Trat } & $\begin{array}{l}\text { Cucba } \\
\text { l }\end{array}$ & Cucba 2 & Salitre & Cucba I & Cucba 2 & Salitre & Cucba I & Cucba 2 & Salitre \\
\hline & \multicolumn{3}{|c|}{${ }^{\circ} \mathrm{BX}$ Refrigerated for $25 \mathrm{ddf}$} & \multicolumn{3}{|c|}{ Ear length at 25 daf } & \multicolumn{3}{|c|}{ Ear diameter at 25 daf } \\
\hline HT8 & 14.2 & 23 & 23.2 & 16.9 & 16.8 & 15.2 & $4.3^{* *}$ & 4 & 3.4 \\
\hline HTIO & 12.4 & 11.9 & 20.2 & 16.5 & 16.7 & 12.6 & $4.5^{* *}$ & 4.1 & 3.4 \\
\hline hsII & 11.5 & $20.9 * *$ & 23.3 & 16.7 & 17.1 & 16.9 & $4.4^{* *}$ & 4.3 & 3.7 \\
\hline HTI2 & 16.8 & $21.3 * *$ & 22.6 & 15.3 & 15.2 & 13.9 & 4.7 & 4.2 & 3.9 \\
\hline HTI6 & 13.2 & $22.5 * *$ & 25.2 & 16.9 & 16.4 & 15.1 & $4.3^{* *}$ & 4 & 3.6 \\
\hline HTI8 & 16.3 & $22.1 * *$ & 18.6 & 15.8 & 17 & 15.2 & $4.4^{* *}$ & 4.3 & 3.7 \\
\hline hs 19 & 15.3* & 15.6 & 19.7 & 17.3 & 16.5 & $9.9 *$ & 4.7 & 4.4 & $3.1^{* *}$ \\
\hline HT20 & 13.5 & $21.1^{* *}$ & 21.7 & 17.5 & 16.3 & 15.8 & $4.4^{* *}$ & $3.7^{* *}$ & 3.7 \\
\hline HT2I & 17 & $21.5^{* *}$ & 26 & 13.9 & 16.1 & 13 & $4.6^{* *}$ & 4.4 & 3.4 \\
\hline HT29 & 13.4 & 14.5 & 19.5 & 16.4 & 17.1 & 10.8 & 4.5 & 4 & 3.7 \\
\hline HT36 & 17.3 & I5.I & 21.1 & 18.1 & 17.4 & 15.9 & 4.7 & 4.2 & 3.7 \\
\hline TEST & 8.6 & 9.3 & 16 & 16.2 & 15.5 & 15 & 4.9 & 4.5 & 4 \\
\hline
\end{tabular}

†Means of most representative variables: Trat , treatments; HT, trilinear hybrids; hs, single hybrids; test, Reference; daf , days after flowering; controls, $*=\mathrm{P} \leq$ $0.05 ; * *=\mathrm{P} \leq 0.01$

\section{Conclusion}

Results obtained in this work confirm the possibility of obtaining varieties and hybrids of sweet corn with high potential in yield and quality of grain for fresh corn consumption due to sweetness $s u 1$ gene obtained from native Mexican corn. Combinations of traditional varieties of landraces Maíz Dulce and Dulcillo del Noroete, along with other elite lines with good combinatorial capacities can be the base germplasm that could establish heterotic patterns. Based in the results of two years, it was possible to demonstrate that modifying native sweet maize through non-sweet but outstanding normal lines is especially useful. Due to the existence of genotype-environment interactions, more evaluations in a wide range of environmental and management conditions will be required.

\section{Acknowledgments}

I am grateful to my wife Veronica Molina, teachers, advisors, students, and colleague researchers for their continuous encouragement in my scientific research.

\section{Conflicts of interest}

Authors declare no conflict of interest exists. carry non-desirable characteristics, like great height of the plant, and susceptibility to stalk and root lodging, and ear diseases. In location El Salitre, differences highly significant between treatments $(\mathrm{P} \leq$ 0.01) for variables (Peso25), (AMZ), and (ALPL), and significant differences $(\mathrm{P} \leq 0.05)$ for variable (DIAM) were obtained, while for variables $\left({ }^{\circ} \mathrm{B} \times 25\right)$ and $\left({ }^{\circ} \mathrm{B} \times 25 \mathrm{r} 30\right)$ there was no significance (Table 6). In CUCBA2 corn weighted less but had a higher percentage of ${ }^{\circ} \mathrm{Bx}$ than in the other two environments. The reason could be that in the second environment at CUCBA, planting was carried out the latter and environmental conditions and water availability, because it was sown in temporary rain and could have been restrictive for the development of the plant and therefore maize had a high percentage of Bx. In the work of Luchsinger and Camilo, ${ }^{8}$ similar results were obtained due to differences in planting dates, where corns planted at a later date were sweeter and, at the same time, maize weight yields were reduced. 
8. Luchsinger LA, Camilo FF. Rendimiento de maíz dulce y contenido de sólidos solubles. Idesia (Chile). 2008;26(3);21-29.

9. Michaels TE, Andrew RH. Sugar accumulation in shrunken-2 Sweet Corn kernels. Crop Sciences. 1986;26:104-107.

10. Coutiño EB, Vidal Martínez VA, Cruz-Gómez B, et al. Aptitud combinatoria general y específica del contenido de azúcares en maíces criollos eloteros. Revista Fitotecnia Mexicana. 2010;33(4):57-61.

11. Marshall SW, Tracy WF. Sweet corn. Corn chemistry and technology In: Ramstad PE. \& White P. editors. 2nd edn. Am Association of Cereal Chemists, Minneapolis, MN. 2003;537-569.
12. Tracy WF, Whitt SR, Buckler ES. Recurrent mutation and genome evolution: example of sugary and the origin of sweet maize. Crop Science. 2006;46.

13. Ramírez Díaz JL, Ledesma Miramontes A, Vidal Martínez V, et al. Selección de maíces nativos como donadores de características agronómicas útiles en híbridos comerciales. Revista Fitotecnia Mexicana. 2015;38:119-131. 